\title{
CORROSION-PREVENTIVE COMPOUNDS FOR INCREASING THE DURABILITY OF PREINSULATED PIPES
}

\author{
JEDINJENJA ZA SPREČAVANJE KOROZIJE I ZA POVEĆANJE TRAJNOSTI \\ PRETHODNO IZOLOVANIH CEVI
}

\author{
Aizada KALMAGAMBETOVA \\ Tatyana BOGOYAVLENSKAYA
}

ORIGINALNI NAUČNI RAD ORIGINAL SCIENTIFIC PAPER UDK:697.433:621.643.2]:620.193.5 doi:10.5937/GRMK1904029K

\section{INTRODUCTION}

In the construction of directly buried hot water networks laying, pipes in thermal insulation made of polyurethane foam with a waterproof outer casing of polyethylene currently occupy a leading place. The most significant advantages of pipes in polyurethane foam (PUR) insulation include: the tightness of the outer waterproof casing that prevents water from entering the thermal insulation layer; equipping pipelines with a measuring wires for surveillance systems; manufacturability in the factory, and, consequently, product quality as a guarantee of durability and service life of the heating network. From the experience in the use of preinsulated bonded pipe systems in Europe, in particular in Germany and Denmark, it is known that the service life of such pipelines can reach up to 50 years. This is stated in most scientific papers on the study of pipes in polyurethane foam insulation (PUR) [1-7].

One of the key parameters affecting the durability and performance of the pipeline in polyurethane foam insulation (PUR) is the adhesion of polyurethane thermal insulation to a steel service pipe and to a waterproof outer casing of polyethylene. This is explained by the fact that the pipeline of the heat network under operating conditions (for example, operation pressure $1.6 \mathrm{MPa}$, operation temperature $130^{\circ} \mathrm{C}$ ) experiences thermal

Aizada Kalmagambetova, candidate of technical sciences, docent of Karaganda State Technical University, Karaganda, N. Nazarbayeva 56, Kazakhstan

Tatyana Bogoyavlenskaya, PhD Student of Karaganda State Technical University, Karaganda, N. Nazarbayeva 56, Kazakhstan

e-mail: t.bogoyavlenskaya88@gmail.com movements as a result of thermal expansion of materials. In this case, the steel service pipe, polyurethane thermal insulation and waterproof outer casing of polyethylene should work as a unit and form a rigid structure.

In the majority of works on the study of adhesion at the edge "Service steel pipe- Polyurethane thermal insulation", as well as "Waterproof outer casing of polyethylene - Polyurethane thermal insulation", for example, the problems of creating a test centre with the aim of testing pipe specimens for axial and tangential shear, allowing to determine the amount of adhesion of PUR, are reviewed in work [8]; the authors proposed the usage of plasma jets of polyethylene processing to improve the adhesive properties in reference to polyurethane foam in work [9].

The importance of the PUR adhesion indicator in terms of shear strength in the tangential direction is that it characterizes the ability of a rigid structure to transmit the force of thermal expansion of a steel service pipe to the outer casing of polyethylene. With sufficient structural strength, sliding occurs along "Outer casing of polyethylene - Ground" edge, and the pipe with insulation moves as a unit $[10,11]$.

It should be noted that the violation of the integrity of the insulation design at the edge «Waterproof outer casing of polyethylene - Polyurethane thermal insulation» leads to delamination of the waterproof casing of polyethylene from the thermal insulation layer, which, in turn, leads to damage to the insulation as a whole. In the case when the waterproof outer casing of polyethylene separated, when installing the pipe joints at the stage of checking the muff joints, it is not able to withstand the standard pressure of 0.5 bar for 5 minutes [11]. The result of damage to the muff joints is loss of tightness and wetting of thermal insulation, resulting in 
an increase in heat loss, corrosion of the steel service pipe and a decrease in the insulation resistance of the measuring wires for surveillance systems.

With this approach, first of all, difficulties arise with pipeline waterproofing of the heating network. Currently, outer casing made of high density polyethylene (HDPE) are used as waterproofing of polyurethane foam thermal insulation of pipes manufactured in the factory, since their advantages are sufficient resistance to cracking and mechanical stress; resistance to ultraviolet radiation, high density, high strength, easy processability $[12,13]$.

Despite the advantages of a waterproof outer casing of polyethylene, depending on the diameter of the pipes, the adhesion rate at the "Waterproof outer casing of polyethylene - Polyurethane thermal insulation" edge decreases. This is due to the complexity of pipes manufacture using the "pipe-in-pipe" technology. Thermal insulation and waterproofing, polyurethane foam and waterproof outer casing of polyethylene are different in their resistance to materials and chemical composition. In this regard, corona effect technology is usually applied, i.e. surface processing of the outer casing of polyethylene by corona discharge; the formulation of foam components according to the chemical composition and ratio is selected; mechanical processing of the surface of the steel service pipe is made; temperature conditions in the factory is withstood; air-tight insulation plugs and other nuances of the technology for the production of preinsulated bonded pipe systems are used to improve the adhesion at the factory.

In order to extend the life of preinsulated bonded pipe systems used as a building material for directly buried hot water networks from standard 30 years to 50 years or more, in this work it is proposed to use corrosion-preventive compound from polyurea as a waterproof coating. Polyurea is used in construction as waterproofing of foundations, wells, structural elements of bridges, industrial floor coating [14-19].

\section{METHODS}

We investigated polyurea as a pipe waterproof in polyurethane thermal insulation. The following materials were used as waterproof materials during the tests: high density polyethylene, recommended for use for protecting pipelines of heating networks and polyurea.

To conduct tests for strength at tangential shear at a temperature of $(23 \pm 2)^{\circ} \mathrm{C}$, an installation at the pipe insulation plant has been developed that allows testing pipes with a diameter of up to $219 \mathrm{~mm}$ inclusive, shown in the photo, Figure 1.

The principle of operation of the installation is to measure the tangential shear of the insulation relative to the steel service pipe, or waterproof coating relative to the layer of polyurethane foam. A specimen of a pipe fragment is motionlessly welded to a metal frame. A tangential load was applied to the waterproof of the pipe using two levers $1000 \mathrm{~mm}$ long, located coaxially horizontally on both sides of the sheath. The speed of the load application to the ends of the levers was 25 $\mathrm{mm} / \mathrm{min}$. The unwinding in the tangential direction occurs until the first signs of delamination appear along the boundaries of "Service steel pipe- Polyurethane thermal insulation" or "Waterproof outer casing of polyethylene - Polyurethane thermal insulation".

At this installation, tests of specimens of steel service pipe fragments were carried out. Fragments of a pipe with an outer diameter of $57 \mathrm{~mm}$, a wall thickness of 4.5 $\mathrm{mm}$, in polyurethane thermal insulation, waterproof outer casing of polyethylene vs. with polyureacoating with a length equal to 0.75 of the diameter of the steel pipe were taken as specimens, the Photos are shown in Figure 2.

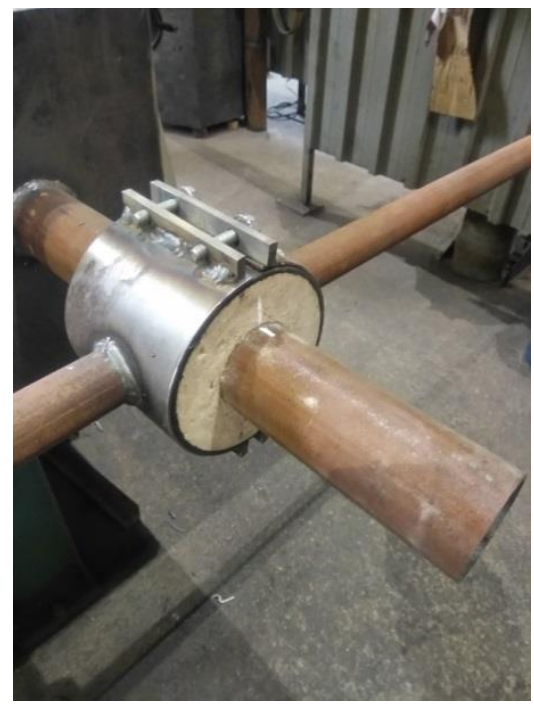

Figure 1 - Installation for determining the shear strength in the tangential direction

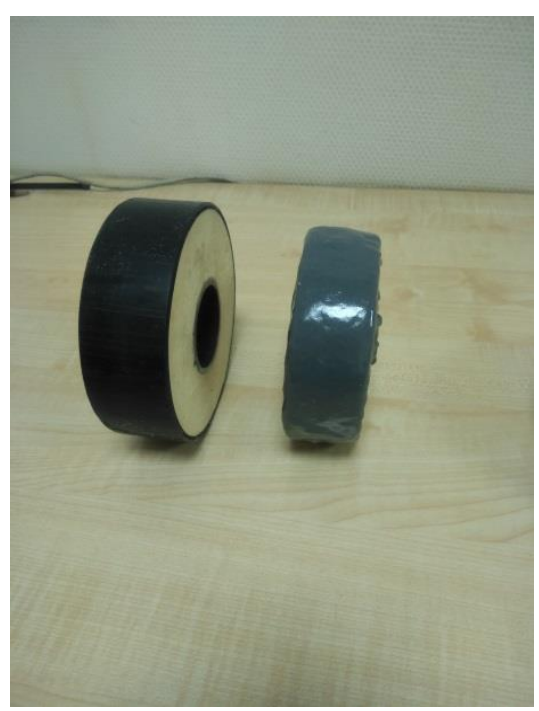

Figure 2 - Specimens of the pipe. On the left: in outer casing of polyethylene. On the right: with polyurea coating

In the manufacture of specimens in the factory, steel service pipes were preliminarily cleaned from corrosion products in a sandblasting installation; PUR components were poured into the space between the steel service pipe and the outer casing of polyethylene on a highpressure filling machine. The thickness of the thermal 
insulating layer was $31.5 \mathrm{~mm}$. The thickness of the outer casing of polyethylene was $2.5 \mathrm{~mm}$. The thickness of the polyurea coatings was $1 \mathrm{~mm} ; 1.5 \mathrm{~mm}$ and $2.5 \mathrm{~mm}$, respectively.

The shear strength in the tangential direction $\tau$ tan, $\mathrm{MPa}$, is calculated from the following formula:

$$
\tau_{\tan }=\frac{2 \cdot l \cdot F_{\tan }}{\pi \cdot d^{2} \cdot L}
$$

where Ftan - the tangential force, in $\mathrm{N}$;

$\mathrm{L}$ - length of specimen, in $\mathrm{mm}$;

$\mathrm{d}$ - outside diameter of the service pipe, in $\mathrm{mm}$;

$\mathrm{I}$ - length of each lever, in $\mathrm{mm}$

In the process of testing, the effect of corrosionpreventive compounds of polyurea on the adhesion strength of polyurethane foam thermal insulation with corrosion-preventive compound was determined. Determination of the adhesion strength of polyurethane foam thermal insulation with corrosion-preventive compound was carried out 10 days after the manufacture of the specimens and 180 days after their storage in an unheated room.

The influence of an aggressive environment was determined, as well as the behaviour of the waterproof composition of polyurea in the ground according to the procedure described in [20]. For the test, a simulated environment of the actual conditions for directly buried hot water networks was created. The basis is pure sand with a moisture content of over $0.5 \%$ and a grain size of $4 \mathrm{~mm}$. A specimen pipe fragment was installed in a sandbox. Installation diagram in Figure 3.

Hot water circulated through the fragment of a steel pipe in insulation (specimen) for 24 hours with parameters $120 \pm 20 \mathrm{C}$. The box was filled with sand 1 meter high (imitation of ground pressure $18 \mathrm{kN} / \mathrm{m} 2$ ). The axial movement of the pipe fragment in insulation by 75 $\mathrm{mm}$ was performed at a speed of $10 \mathrm{~mm} / \mathrm{min}$. Thus, 100 cycles were performed, where one cycle is considered to be moving forward and backward.

The thermal conductivity of the pipe fragment was determined according to the procedure presented in [11]. For this purpose, an experimental setup was made, shown in Figure 4. It is a steel service pipe with the outer diameter of $57 \mathrm{~mm}$ and the length of 1 meter. A heating element mounted on a fire-resisting material was placed inside the pipe. The steel pipe was heated to a temperature of $50^{\circ} \mathrm{C}$. Indications of thermal conductivity were measured by a wattmeter and thermocouples.

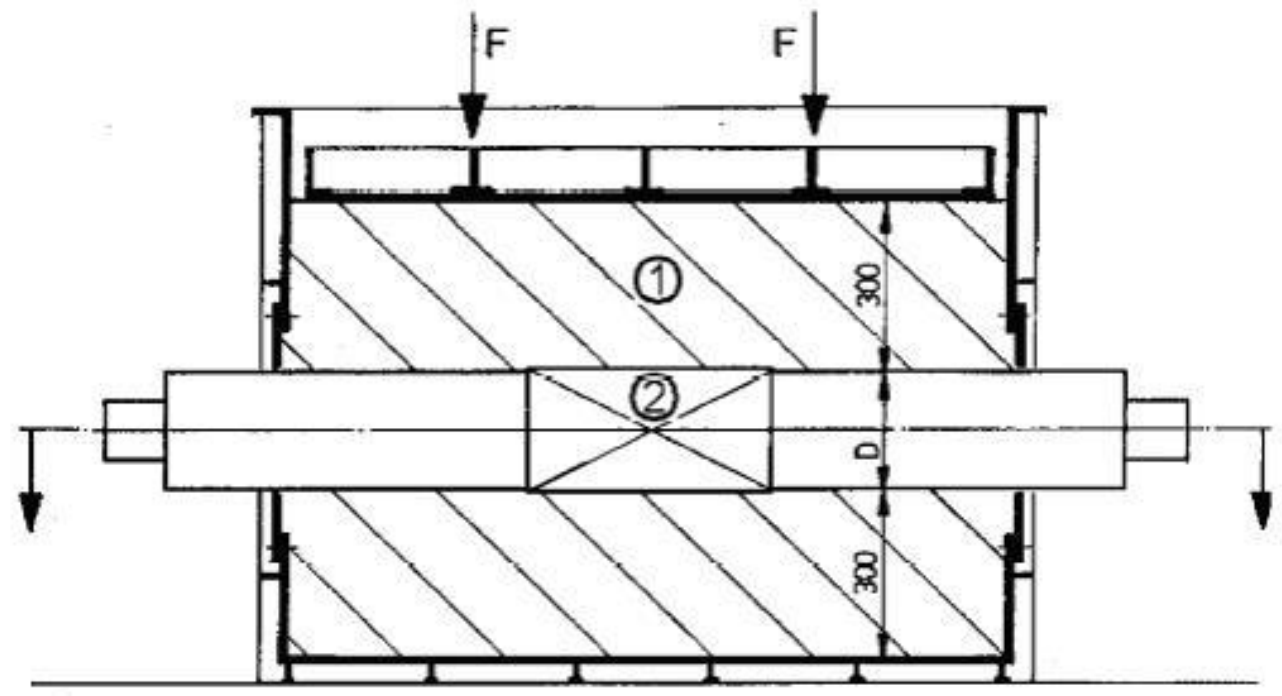

Figure 3 - Diagram of a test box with sand. 1 - sand; 2 -steel service pipe fragment in insulation

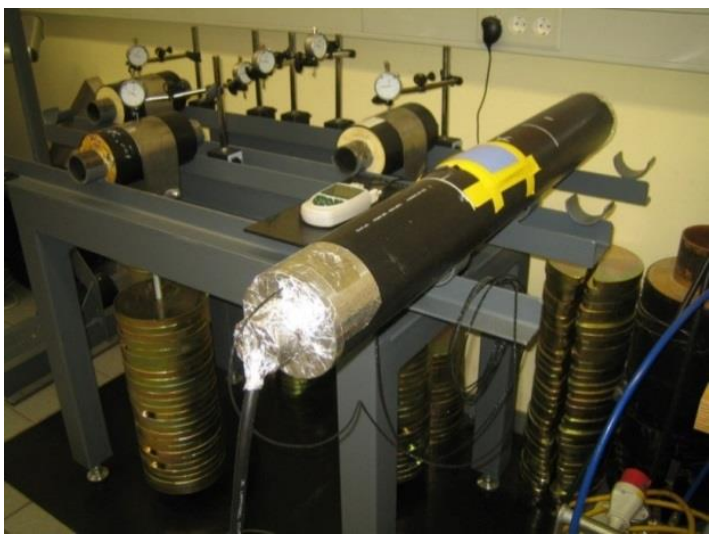

Figure 4 - Experimental setup for thermal conductivity measuring 


\section{RESULTS AND DISCUSSION}

The test results of determining the specimens shear strength are presented in table 1.

A comparative analysis of the fracture pattern of the specimens showed that there is fracture along the edge "Waterproof outer casing of polyethylene - Polyurethane thermal insulation", adhesion of polyurea and polyurethane thermal insulation has better performance than that of outer casing of polyethylene and polyurethane thermal insulation. The test results further confirm that much attention needs to be paid to the strength of the joint between structure components.

The fracture along the edge "Waterproof outer casing of polyethylene - Polyurethane thermal insulation" is the result of insufficient adhesion of polyurethane foam to the outer casing material - polyethylene. This is due to differences in the chemical structure of the adhesion of polyurethane foam and polyethylene, and the adhesion of polyurethane foam to unprocessed polyethylene is practically absent. The adhesion is also negatively affected by the long filling time of the structure (the socalled late filling), as far as in this case a foam with a low content of functional groups that are capable of forming adhesive bonds comes into contact with polyethylene. Polyurea coatings with a thickness of $1 \mathrm{~mm}$ have the best bonding. Figure 5 shows a graph of the dependence of the tangential shear strength on the wall thickness of the coating.

The test results of the specimens for behaviour in an aggressive environment are presented in table 2 .

Test results show that specimens with a waterproofing polyurea coating also sustain 100 cycles. This means that polyurea, according to its technical characteristics, can be used in an aggressive environment, such as sand, and does not wear out. This indicator is important because of the real movements of the pipeline in the ground for directly buried hot water networks during thermal expansion.
To compare the heat loss through the structure, a calculation was carried out, taking into account the results of measuring the thermal conductivity of the pipe structure with insulation, determined at the experimental installation.

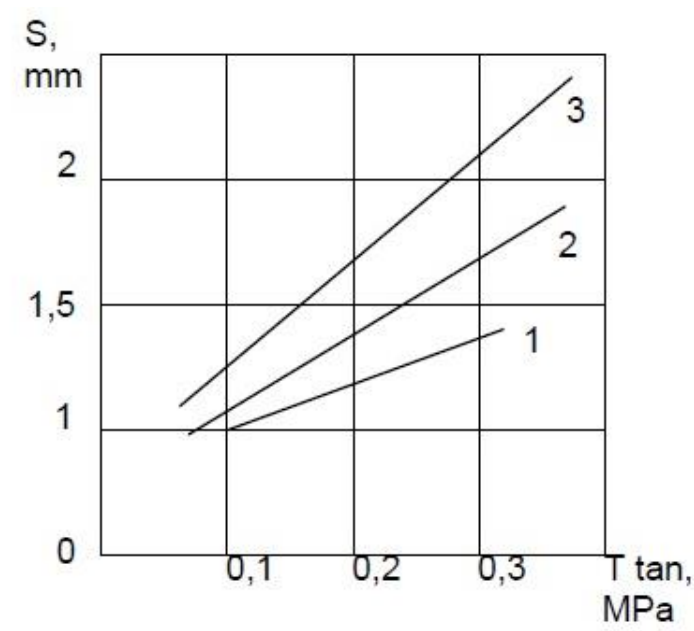

Figure 5 - Dependence of the tangential shear strength indicator on the coating wall thickness (for polyurea): 1 for a specimen with a wall thickness of $1 \mathrm{~mm} ; 2$ - for a specimen with a wall thickness of $1.5 \mathrm{~mm}$; 3 - for a specimen with a wall thickness of $2 \mathrm{~mm}$

The calculations of the energy characteristics of water heating networks by the "heat loss" indicator for pipelines for directly buried hot water networks are presented below. For the initial data for the calculation, the following indicators are taken in table 3.

Table1. Test results for determining the adhesion of polyurethane foam thermal insulation with waterproof material

\begin{tabular}{|c|c|c|}
\hline specimen party a & $\begin{array}{c}\text { Shear strength in the tangential direction } \tau \text { tan, } \\
\text { MPa, (average) after 10 days of storage after } \\
\text { pouring the specimen in outer casing of } \\
\text { polyethylene }\end{array}$ & $\begin{array}{c}\text { Shear strength in the tangential direction } \tau \text { tan, } \\
\text { MPa, (average) after 10 days of storage after } \\
\text { coating the specimen with a polyurea }\end{array}$ \\
\hline 1 & 0,2 & 0,3 \\
\hline 2 & 0,23 & 0,35 \\
\hline 3 & 0,25 & 0,4 \\
\hline
\end{tabular}

Table 2. Test results of specimens for behaviour in an aggressive environment

\begin{tabular}{|c|c|c|c|}
\hline $\begin{array}{c}\text { specimen } \\
\text { party ą }\end{array}$ & Indicator & $\begin{array}{c}\text { A specimen of a steel service pipe with } \\
\text { outer diameter of } 57 \mathrm{~mm} \text { in } \\
\text { polyurethane foam insulation and outer } \\
\text { casing of polyethylene }\end{array}$ & $\begin{array}{c}\text { A specimen of a steel service pipe with } \\
\text { outer diameter of } 57 \text { mm in polyurethane } \\
\text { foam insulation with a waterproof coating } \\
\text { of polyurea }\end{array}$ \\
\hline 1 & Sustain of 100 cycles & Sustained & sustained \\
\hline
\end{tabular}


Table 3. Characteristic Values

\begin{tabular}{|c|c|c|}
\hline Indicator & $\begin{array}{l}\text { Specimen of a pipe in } \\
\text { polyethylene sheath }\end{array}$ & $\begin{array}{l}\text { Specimen of a pipe in a } \\
\text { polyurea sheath }\end{array}$ \\
\hline Steel service pipe outer diameter, in mm & 57 & 57 \\
\hline Wall thickness of steel service pipe, $\mathrm{mm}$ & 4,5 & 4,5 \\
\hline Insulation thickness on the supply and return pipes, $\mathrm{mm}$ & 78,9 & 78,9 \\
\hline The outer diameter of the casing, $\mathrm{mm}$ & 125 & 122 \\
\hline Thermal conductivity of insulation materialëi, $\mathrm{W} / \mathrm{m}^{\star} \mathrm{K}$ & 0,033 & 0,022 \\
\hline Thermal conductivity of casingë $\mathrm{HDPE}, \mathrm{W} / \mathrm{m}^{*} \mathrm{~K}$ & 0,43 & 0,21 \\
\hline Thermal conductivity of groundëground, $\mathrm{W} / \mathrm{m}^{*} \mathrm{~K}$ & 1,2 & 1,2 \\
\hline The distance between the pipelines, $\mathrm{mm}$ & 250 & 250 \\
\hline Depth of laying to the axis of the pipeline (directly buried) $\mathrm{Hm}, \mathrm{mm}$ & 862,5 & 861 \\
\hline The distance between the axes of the pipelines, $a, m$ & 375 & 372 \\
\hline Annual average temperature of the supply pipeline, Vs, ${ }^{0} \mathrm{~N}$ & 120 & 120 \\
\hline Annual average temperature of return pipeline $\mathrm{Vr},{ }^{0} \mathrm{~N}$ & 60 & 60 \\
\hline Annual average temperature of ground, $\mathrm{Vg},{ }^{0} \mathrm{~N}$ & 10 & 10 \\
\hline
\end{tabular}

The thermal resistance of the pipe $[1 / K R]$ was calculated in accordance with the equation for multilayer pipes according to the formulas presented in [11] as follows:
The calculation was made for the specimen pipe in polyurethane foam insulation and outer casing of polyethylene:

$$
\frac{1}{K R}=\frac{1}{2 \cdot \pi \cdot \lambda_{i}} \cdot \ln \left(\frac{D i}{d a}\right)+\frac{1}{2 \cdot \pi \cdot \lambda_{H D P E}} \cdot \ln \left(\frac{D a}{D i}\right)+\frac{1}{2 \cdot \pi \cdot \lambda_{\text {ground }}} \cdot \ln \left(\frac{4 \cdot H m}{D a}\right)+\frac{1}{2 \cdot \pi \cdot \lambda_{\text {ground }}} \cdot \ln \left(1+\frac{2 \cdot H m}{a^{2}}\right)
$$

Here, In is the natural logarithm, $D a$ is the outer diameter of the casing, $\mathrm{mm}$; $D i$ is the inner diameter of the casing, $\mathrm{mm}$; da is the outer diameter of the steel service pipe, $\mathrm{mm}$; di is the inner diameter of the steel service pipe, $\mathrm{mm}$.

Heat loss per 1 meter of pipe was calculated:

$$
Q R T=2 \cdot K R \cdot V M
$$

Here, $Q R T$ is the heat loss, W/m; KR - heat flux, W; $V M$ - annual average temperature of the pipeline, ${ }^{\circ} \mathrm{C}$.

The annual average temperature of the pipeline was calculated by the formula:

$$
V M=\frac{V_{s}+V_{r}}{2}-V_{\text {ground }}
$$

Here, Vs - is the annual average temperature of the supply pipeline,${ }^{\circ} \mathrm{C}$; $\mathrm{Vr}$ - annual average return pipeline temperature, ${ }^{\circ} \mathrm{C} ; \mathrm{Vg}$ - annual average ground temperature, ${ }^{\circ} \mathrm{C}$.

$$
\begin{gathered}
\frac{1}{K R}=\frac{1}{2 \cdot 3,14 \cdot 0,033} \cdot \ln \left(\frac{125}{57}\right)+\frac{1}{2 \cdot 3,14 \cdot 0,43} \cdot \ln \left(\frac{125}{120}\right)+ \\
+\frac{1}{2 \cdot 3,14 \cdot 1,2} \cdot \ln \left(\frac{4 \cdot 862,5}{125}\right)+\frac{1}{2 \cdot 3,14 \cdot 1,2} \cdot \ln \left(1+\frac{2 \cdot 862,5}{375^{2}}\right)=4,03 \\
\frac{1}{K R}=4,03 \\
Q R T=2 \cdot 0,248 \cdot 80=39,68 \mathrm{~W} / \mathrm{m} \\
V M=\frac{120+60}{2}-10=80^{\circ} \mathrm{C}
\end{gathered}
$$

The similar calculation was made for a pipe specimen with waterproof coating of polyurea:

$$
\begin{gathered}
\frac{1}{K R}=\frac{1}{2 \cdot 3,14 \cdot 0,022} \cdot \ln \left(\frac{122}{57}\right)+\frac{1}{2 \cdot 3,14 \cdot 0,21} \cdot \ln \left(\frac{122}{120}\right)+ \\
+\frac{1}{2 \cdot 3,14 \cdot 1,2} \cdot \ln \left(\frac{4 \cdot 861}{122}\right)+\frac{1}{2 \cdot 3,14 \cdot 1,2} \cdot \ln \left(1+\frac{2 \cdot 861}{372^{2}}\right)=5,95 \\
\frac{1}{K R}=5,95
\end{gathered}
$$

$Q R T=2 \cdot 0,168 \cdot 80=26,88 \mathrm{~W} / \mathrm{m}$ 
As a result of numerical experiments with varying the thickness of waterproofing, it was found that the waterproofing thickness of $1 \mathrm{~mm}$ polyurea is optimal, providing a low amount of heat loss, as in the case of a $2.5 \mathrm{~mm}$ thick casing of polyethylene for a test specimen of a $57 \mathrm{~mm}$ outer diameter steel service pipe. This is evidenced by a comparative analysis of the results of calculations on the indicator of "heat loss" of pipes with waterproofing from polyurea and polyethylene, presented in table 4.

Table 4. A comparative analysis of pipe specimens on "Heat loss" indicator

\begin{tabular}{|c|c|c|c|}
\hline $\begin{array}{c}\text { specimen } \\
\text { party ą }\end{array}$ & Indicator & $\begin{array}{c}\text { A specimen of a steel service pipe with } \\
\text { outer diameter of } 57 \mathrm{~mm} \text { in polyurethane } \\
\text { foam insulation and outer casing of } \\
\text { polyethylene }\end{array}$ & $\begin{array}{c}\text { A specimen of a steel service pipe with } \\
\text { outer diameter of } 57 \mathrm{~mm} \text { in } \\
\text { polyurethane foam insulation with a } \\
\text { waterproof coating of polyurea }\end{array}$ \\
\hline 1 & $\begin{array}{c}\text { The coefficient of } \\
\text { thermal conductivity, } \\
\mathrm{W} / \mathrm{m}^{\star} \mathrm{K}\end{array}$ & 0,033 & 0,022 \\
\hline 2 & Heatloss, W/m & 39,68 & 26,88 \\
\hline 3 & $\begin{array}{c}\text { Assessment of } \\
\text { efficiency }\end{array}$ & & $30 \%$ less of heat loss per meter of a \\
pipe
\end{tabular}

\section{CONCLUSIONS}

1. A comparative analysis of the nature of the demolition of the specimens showed that there is demolition along the edge "Waterproof outer casing of polyethylene - Polyurethane thermal insulation".

2. The strength properties of individual elements fail to give a complete picture of the strength and performance of the structure of pre-insulated pipes as a whole.

3. Extending the life of pipes for hot water networks from standard 30 years to 50 years or more is possible when corrosion-preventive compounds made of polyurea are used as a waterproof coating.

4. It is possible to reduce the wall thickness of a waterproofing coating based on polyurea from a standard of $2.5 \mathrm{~mm}$ to $1 \mathrm{~mm}$.

5. The use of polyurea as waterproof coating for pipes with thermal insulation from polyurethane foam is possible.

6. The use of polyurea as waterproof coating for pipes with thermal insulation from polyurethane foam can reduce heat loss per meter by $30 \%$.

\section{REFERENCES}

[36] Slepchenok V.S., Petrakov G.P. Increasing the energy efficiency of thermal insulation of heat network pipelines in Northern and Northeastern regions of Russia // Magazine of Civil Engineering. 2011. 4(22). Pp. 26-32. DOI: 10.5862/MCE.22.4.

[37] Turski, Michał, Sekret, Robert. Buildings and a district heating network as thermal energy storages in the district heating system. Energy and Buildings. 2018. Vol.179. Pp. 49-56. DOI: 10.1016/J.ENBUILD.2018.09.015

[38] Kayfeci, Muhammet. Determination of energy saving and optimum insulation thicknesses of the heating piping systems for different insulation materials. Energy and Buildings. 2014. Vol.69. Pp. 278-284. DOI: 10.1016/J.ENBUILD.2013.11.017
[39] Petrakov G.P. The service life of plastic pipes in polyurethane foam insulation used for heating systems // Magazine of Civil Engineering. 2012. No 3 (29). Pp. 54-62. 10.5862 / MCE.29.7.

[40] Wang, Hai, Meng, Hua, Zhu, Tong. New model for onsite heat loss state estimation of general district heating network with hourly measurements. Energy Conversion and Management. 2018. Vol.157. Pp. 71-85. DOI: 10.1016/J.ENCONMAN.2017.11.062

[41] Chopra, K., Tyagi, V.V., Pandey, A.K., Sari, Ahmet. Global advancement on experimental and thermal analysis of evacuated tube collector with and without heat pipe systems and possible applications. Applied Energy. 2018. Vol.228. Pp. 351-389. DOI: 10.1016/J.APENERGY.2018.06.067

[42] Danielewicz, J., Śniechowska, B., Sayegh, M.A., Fidorów, N., Jouhara, $\mathrm{H}$. Three-dimensional numerical model of heat losses from district heating network pre-insulated pipes buried in the ground. Energy. 2016. Vol.108. Pp. 172-184. DOI:10.1016/J.ENERGY.2015.07.012

[43] Korolev I.A., Petrakov G.P. Creation of a testing center for checking the quality of polyurethane foam insulation of pre-insulated pipelines used in heat supply systems // Magazine of Civil Engineering. 2010. No. 1 (11). Pp. 23-25. DOI: 10.18720 / MCE.11.6.

[44] Yu. S. Akishev, A. V. Petryakov, N. I. Trushkin, V. A. Ustyugov. Improving of the adhesion of polyurethane foam to the low-pressure polyethylene processed by a plasma jet at the atmospheric pressure // Applied Physics. 2017. No. 5. Pp. 20-24.

[45] JörgKauschat. Patent EP2166269B2. Method for connecting cladded pipes. Patent EP2166269B2 // EuropeanPatentOffice. isoplusFernwärmetechnik GmbH. 2017

[46] DIN EN 253-2013. District heating pipes Preinsulated bonded pipe systems for directly buried hot water networks - Pipe assembly of steel service pipe, polyurethane thermal insulation and outer casing of polyethylene. 
[47] DIN EN 448-2009. District heating pipes Preinsulated bonded pipe systems for directly buried hot water networks - Fitting assemblies of steel service pipes, polyurethane thermal insulation and outer casing of polyethylene.

[48] Sadr-Al-Sadati, Syed Ali, JaliliGhazizadeh, Mohammadreza. The experimental and numerical study of waterleakage from High-Density Polyethylene pipes at elevated temperatures Polymer Testing. 2019. Vol.74. Pp. 274-280. DOI: 10.1016/J.POLYMERTESTING.2019.01.014

[49] lqbal N, Sharma P, Kumar D, Roy P. Protective polyurea coatings for enhanced blast survivability of concrete. Construction and Building Materials. 2018. Vol. 175. Pp: 682-690. DOI: 10.1016/J.CONBUILDMAT.2018.04.204

[50] Elnaggar E, Elsokkary T, Shohide M, El-Sabbagh $B$, Abdel-Gawwad $H$. Surface protection of concrete by new protective coating. Construction and Building Materials. 2019. Vol. 220. Pp: 245252. DOI: 10.1016/J.CONBUILDMAT.2019.06.026

[51] Hou H, Chen C, Cheng Y, Zhang P, Tian X, et. al. Effect of structural configuration on air blast resistance of polyurea-coated composite steel plates: Experimental studies. Materials \& Design. 2019. Vol. 182. Pp: 108049. DOI: 10.1016/J.MATDES.2019.108049

\section{ABSTRACT}

\section{CORROSION-PREVENTIVE COMPOUNDS FOR INCREASING THE DURABILITY OF PREINSULATED PIPES}

\section{Aizada KALMAGAMBETOVA \\ Tatyana BOGOYAVLENSKAYA}

The adhesion of polyurethane thermal insulation to a waterproof outer casing of polyethylene in the construction of preinsulated bonded pipe systems used as a building material for directly buried hot water networks is investigated. In order to extend the life of pipes for hot water networks from standard 30 years to 50 years or more, it is proposed to use polyurea as a waterproof coating. It is proposed to determine the adhesion strength of thermal insulation with a waterproof outer casing for shear in the tangential direction at the edge "Waterproof outer casing of polyethylene Polyurethane thermal insulation". Test results are presented. The results of calculations of the heat losses of the preinsulated pipe construction are presented. The testing results of the behaviour of polyurea coating in the ground are presented. Conclusions are drawn about the possibility of using polyurea as a waterproof coating for preinsulated bonded pipe systems for directly buried hot water networks.

Keywords: Building Materials, Durability, Mechanical Properties, Energy Efficiency, Energy Conservation, Heating, Heat Storage, Corrosion, Thermal Insulation, Polymers
[52] He L, Attard T, Zhou H, Brooks A. Integrating energy transferability into the connection-detail of coastal bridges using reinforced interfacial epoxypolyurea reaction matrix composite. Composite Structures. 2019. Vol. 216. Pp: 89-103. DOI: 10.1016/J.COMPSTRUCT.2019.02.094

[53] GairJ, Lambeth R, Cole D, Lidston D, Stein I, et. al. Strong process-structure interaction in stoveable poly(urethane-urea) aligned carbon nanotube nanocomposites. Composites Science and Technology. 2018. Vol. 166. Pp: 115-124. DOI: 10.1016/J.COMPSCITECH.2018.02.011

[54] Zhang F, Ju P, Pan M, Zhang D, Huang $Y$, et. al. Self-healing mechanisms in smart protective coatings: A review. Corrosion Science. 2018. Vol. 144. Pp: 74-88. DOI: 10.1016/J.CORSCI.2018.08.005

[55] DIN EN 489-2009. District heating pipes Preinsulated bonded pipe systems for directly buried hot water networks - Joint assembly for steel service pipes, polyurethane thermal insulation and outer casing of polyethylene.

\section{САЖЕTAK}

\section{ЈЕДИЊЕЊА ЗА СПРЕЧАВАЊЕ КОРОЗИЈЕ И ЗА ПОВЕЋАЊЕ ТРАЈНОСТИ ПРЕТХОДНО ИЗОЛОВАНИХ ЦЕВИ}

\section{Аизада КАЛМАГАМБЕТОВА}

Татуана БОГОУАВЛЕНСКАУА

Испитује се пријањање полиуретанске топлотне изолације на водоотпорно спољно кућиште од полиетилена у конструкцији преинизолираних цевних система који се користе као грађевински материјал за директно закопане топловодне мреже. Да би се продужио век цеви за вреловодне мреже са стандардних 30 на 50 или више година, предлаже се употреба полиурее као водоотпорног премаза. Предлаже се утврђивање чврстоће лепљења топлотне изолације водонепропусним спољним кућиштем за смицање у тангенцијалном смеру на ивици „Водоотпорно спољно кућиште од полиетилена полиуретанска топлотна изолација“. Представљени су резултати испитивања. Приказани су резултати израчуна топлотних губитака предизоловане цеви. Представљени су резултати испитивања понашања полиуреепремаза у земљи. Извучени су закључци о могућности употребе полиурее као водоотпорног премаза за преизолиране цеви за цевоводе за директно закопане топловодне мреже.

Кључне речи: грађевински материјали, издржљивост, механичка својства, енергетска ефикасност, уштеда енергије, грејање, складиштење топлоте, корозија, топлотна изолација, полимери 
